\title{
PENGARUH KUALITAS PELAYANAN DAN KEPUASAN PELANGGAN TERHADAP KEINGINAN BERBELANJA PADA COCO MART TABANAN
}

\author{
Ni Wayan Ari Sudiartini, ,Ni Ketut Murdani, dan Ni Kadek Candra Dewi \\ Fakultas Ekonomi, Universitas Mahendradatta, Jl. Ken Arok No.12, \\ Peguyangan, Denpasar Utara, Kota Denpasar, Bali 80115 \\ Telp/Fax :(0361) 434827/0361-249471, \\ Email : info@mahendradattauniversity.org
}

\begin{abstract}
Abstrak
Penelitian ini bertujuan untuk mengetahui bagaimana pengaruh kualitas pelayanan dan kepuasan pelanggan terhadap keinginan berbelanja pada Coco Mart Tabanan. Data yang digunakan dalam penelitian ini adalah data kuantitatif kemudian diolah menggunakan analisis regresi linear berganda. Populasi dalam penelitian ini adalah konsumen yang melakukan pembelian di Coco Mart Tabanan, dengan sampel 60 orang.

Hasil uji analisis regresi linear berganda diperoleh persamaan $\mathrm{Y}=-0,465+$ $0,236 X_{1}+0,289 X_{2}$, yang artinya variabel kualitas pelayanan $\left(X_{1}\right)$ dan kepuasan pelanggan $\left(\mathrm{X}_{2}\right)$ berpengaruh positif signifikan terhadap keinginan berbelanja $(\mathrm{Y})$. Hasil uji korelasi menunjukkan bahwa koefision korelasi sebesar $=0,889$ terletak antara 0,80-1,00 yang berarti bahwa pengaruh antara kualitas pelayanan $\left(\mathrm{X}_{1}\right)$ dan kepuasan pelanggan $\left(\mathrm{X}_{2}\right)$ dengan keinginan berbelanja $(\mathrm{Y})$ adalah sangat kuat. Hasil uji determinasi, jumlah disesuaikan $\mathrm{R}^{2}$ adalah 0,790 ini berarti pengaruh kualitas pelayanan dan kepuasan pelanggan terhadap keinginan berbelanja sebesar 79,0\% sedangkan sisanya sebesar $21,0 \%$ dipengaruhi oleh faktor lain yang tidak diteliti. Hasil uji f dan uji t menunjukkan bahwa hipotesis yang berbunyi " ada pengaruh yang signifikan antara kualitas pelayanan $\left(\mathrm{X}_{1}\right)$ dan kepuasan pelanggan $\left(\mathrm{X}_{2}\right)$ terhadap keinginan berbelanja (Y)" dapat diterima melalui pengujian taraf signifikan $(\alpha)$ sebesar $0,000<0,05$.
\end{abstract}

Kata Kunci: Kualitas Pelayanan, Kepuasan Pelanggan, dan Keinginan Berbelanja.

\begin{abstract}
This research aims to find out how the influence of service quality and customer satisfaction to desire to shop at Coco Mart Tabanan. The data used in this research is quantitative data and then processed using multiple linear regression analysis. Population in this research were consumers who made purchases in Coco Mart Tabanan, with a sample of 60 people.

Test results of multiple linear regression analysis obtained equation $Y=-$ $0,465+0,236 X_{1}+0,289 X_{2}$, which means the quality of service variables $\left(X_{1}\right)$ and
\end{abstract}


customer satisfaction $\left(X_{2}\right)$ have a significant positive effect on the desire to shop $(Y)$. The correlation test results show that the correlation coefficient of $=0,889$ lies between 0,80-1,00 which means that the effect between service quality $\left(X_{1}\right)$ and customer satisfaction $\left(X_{2}\right)$ with shopping desire $(Y)$ is very strong. Determination test results, adjusted amount of $R^{2}$ is 0,790 this means the influence of service quality and customer satisfaction to the desire to shop for $79,0 \%$ while the remaining 21,0\% influenced by other factors not examined. The results of the f test and t test show that the hypothesis which reads " there is a significant influence between service quality $\left(X_{1}\right)$ and customer satisfaction $\left(X_{2}\right)$ on shopping desire $(Y)$ " can be received by testing significant level 0,000 is smaller than 0,05.

Keywords : Service Quality, Customer Satisfaction, and Shopping Desire.

\section{PENDAHULUAN}

\section{Latar Belakang}

Semakin majunya ekonomi, berkembangnya pasar dan segmentasi pasar sekarang ini telah mengubah secara drastis minat beli konsumen dengan semakin banyaknya macam macam pilihan produk jasa. Konsumen telah memilih ekspektasi yang lebih besar dan lebih menantang daripada sebelumnya. Konsumen sekarang menginginkan produk yang berkualitas tinggi dan harganya bisa dijangkau oleh mereka. Perusahaan harus dapat merebut konsumen dari pesaing dengan memberikan value yang lebih besar dan perusahaan yang ingin berkembang serta ingin mendapatkan keunggulan kompetitif harus dapat memberikan produk atau jasa yang berkualitas kepada para pelanggan, sehingga akan muncul kepuasan dalam benak konsumen dan untuk kembali belanja.

Bentuk perusahaan yang berkembang pada saat ini adalah minimarket. Salah satunya PT Bali Pawiwahan (Coco Group). PT Bali Pawiwahan (Coco Group) dirintis tahun 1998 oleh pengusaha lokal Bali yang memiliki cita-cita luhur dan sangat tinggi untuk membuat sebuah perusahaan lokal yang berskala besar, perusahaan diawali dari sebuah toko kecil yang berlokasi di Bali Galeria Nusa Dua (sekarang Bali Collection).

Pada tahun 2000 perusahaan ini mulai membuka beberapa cabang di Bandara Ngurah Rai Internasional dan Domestic, seperti BPWI, Bina Pura, BPW3 dan toko lainnya. Tahun 2006 perusahaan mengembangkan usahanya lagi, kali ini mencoba pangsa pasar lokal dengan nama Coco Mart pada tanggal 25 Maret 2006. Di tahun yang sama tepatnya 20 November 2006 perusahaan juga membuka Coco Supermarket di area Bali Collection. Hingga kini perusahaan terus berkembang seiring dengan semakin banyaknya para para profesionalis yang bergabung di Coco Group. 
Tabel

Data Penjualan Coco Mart Tahun 2013-2017

\begin{tabular}{|c|c|c|c|}
\hline No & Tahun & Data Penjualan & $\begin{array}{c}\text { Persentase } \\
\text { Penjualan }\end{array}$ \\
\hline 1 & 2013 & Rp. 6.387 .500 .000 & $5 \%$ \\
\hline 2 & 2014 & Rp. 6.706.875.000 & $5 \%$ \\
\hline 3 & 2015 & Rp. 7.109.287.500 & $6 \%$ \\
\hline 4 & 2016 & Rp. 7.678. 030.500 & $8 \%$ \\
\hline 5 & 2017 & Rp. 8.061.922.025 & $5 \%$ \\
\hline
\end{tabular}

Sumber : Coco Mart Taman Griya

Berdasarkan data Tabel 1.1 diatas, dapat dilihat bahwa penjualan Coco Mart Taman Griya meningkat setiap tahunnya. Terlihat pada tahun 2013 total penjualan Coco Mart Taman Griya Rp. 6.387.500.000 kemudian, pada tahun 2014 penjualan mengalami peningkatan sebanyak $5 \%$ , diikuti tahun 2015 sebanyak 6\%, tahun 2016 sebanyak $8 \%$ dan puncaknya pada tahun 2017 mengalami peningkatan yang cukup signifikan sebanyak 5\% dengan total penjualan Rp. 8.061.922.025.

Maka dari itu, untuk meningkatkan penjualan kualitas pelayanan perlu diperhatikan karena kualitas pelayanan merupakan faktor penting yang harus diperhatikan setiap perusahaan untuk mendapatkan kepuasan pelanggan. Kualitas pelayanan merupakan suatu kondisi dinamis yang berhubungan dengan produk jasa, manusia, proses dan lingkungan yang mampu memenuhi dan atau melebihi harapan konsumen. Kualitas pelayanan yang baik juga harus dilaksanakan demi kelangsungan hidup suatu perusahaan, baik tidaknya kualitas pelayanan barang atau jasa tergantung pada kemampuan produsen dalam memenuhi harapan konsumen secara konsisten. Konsumen yang merasa puas tidak langsung akan menciptakan loyalitas, secara dan mendorong terjadinya rekomendasi dari mulut kemulut, bahkan dapat memperbaiki citra perusahaan dimata konsumen.

\section{Perumusan Masalah}

Berdasarkan latar belakang masalah yang telah dikemukakan diatas, maka masalah yang dirumuskan dalam penelitian ini adalah sebagai berikut :

1. Apakah kualitas pelayanan dan kepuasan pelanggan berpengaruh terhadap keinginan berbelanja di Coco Mart Tabanan?

2. Apakah kualitas pelayanan berpengaruh terhadap keinginan 
berbelanja pelanggan di Coco Mart Tabanan?

3. Apakah kepuasan pelanggan berpengaruh

keininginan

pelanggan di Coco Mart

Tabanan?

\section{METODOLOGI PENELITIAN}

\section{Rancangan / Desain Penelitian}

Rancangan penelitian adalah rancangan model yang dibangun dalam penelitian, sehingga kegiatan pengumpulan dan pengolahan data dapat dilaksanakan dengan baik dan benar untuk mencapai tujuan penelitian. Penelitian ini dilakukan dengan cara melakukan survei secara langsung pada Coco Mart Kabupaten Tabanan untuk mengumpulkan data pendukung.

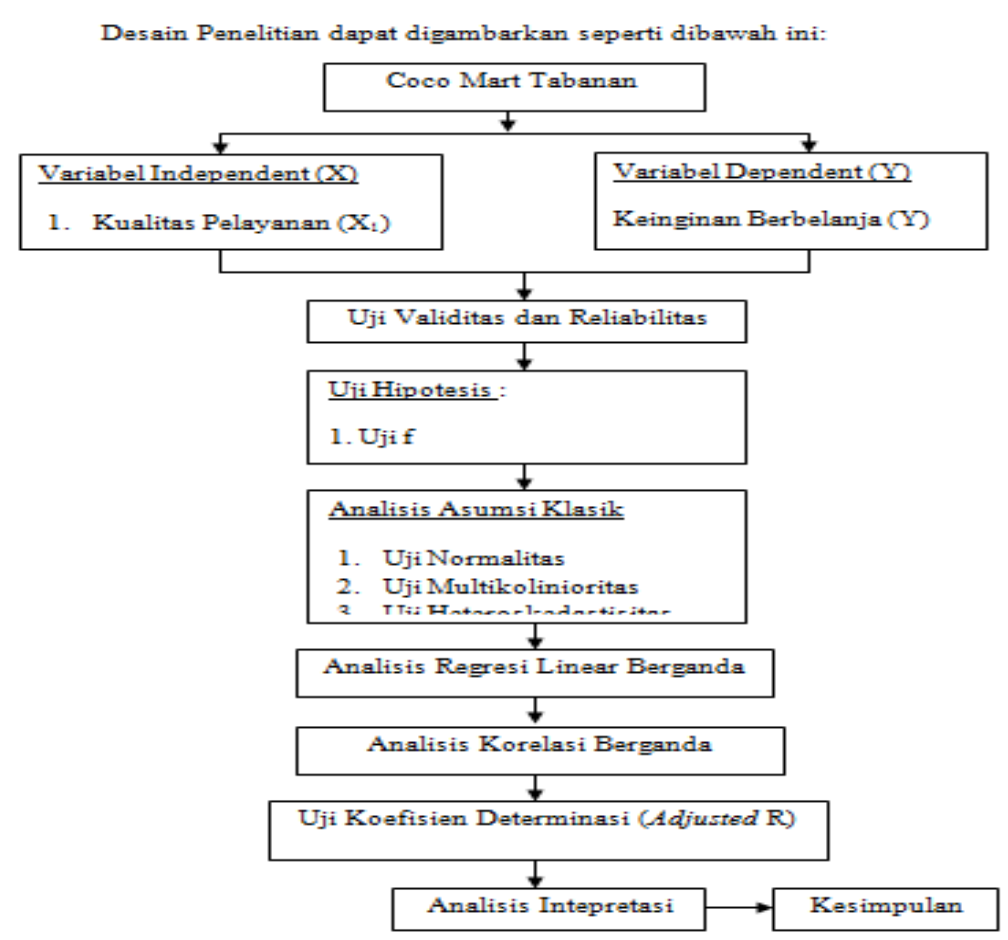

\section{Metode Pengumpulan Data}

Pengumpulan data yang dilakukan dalam penelitian ini adalah menggunakan metode survei dengan dua cara untuk pengumpulan data yaitu sebagai berikut :

a. Data Primer

b. Observasi c. Wawancara

d. Kuesioner

e. Data Sekunder

f. Studi Pustaka

g. Studi Dokumen

Teknik Analisis Data

a. Uji Validitas Instrumen Penelitian

Uji Validitas yaitu pengujian tingkat ketepatan menggunakan alat pengukur terhadap suatu gejala atau kejadian. 


\section{b. Uji Reliabilitas}

Uji Reliabitas yaitu istilah yang dipakai untuk menunjukan sejauh mana suatu hasil pengukur relatif konsisten apabila pengukuran dilakukan dua kali atau lebih.

c. Analisis Asumsi Klasik

- Uji Normalitas

Uji ini bertujuan untuk menguji apakah dalam model regrasi variabel pengganggu atau residual memiliki distribusi normal.

- Uji Multikolinieritas

Uji ini bertujuan untuk menguji apakah dalam model regrasi ditemukan adanya korelasi antar variabel bebas (variabel independent).

\section{- Uji} Heteroskedastisitas

Uji ini bertujuan untuk menguji apakah dalam suatu model regresi terjadi ketidaksamaan varians dari residual satu pengamatan ke pengamatan lain.

\section{- Analisis Korelasi} Berganda

Analisis korelasi berganda merupakan perluasan dari analisis korelasi sederhana.

- Uji Koefisien Determinasi $\left(\mathrm{R}^{2}\right)$

Uji koefisien determinasi $\left(R^{2}\right)$ digunakan untuk mengukur seberapa jauh kemampuan model dalam menerangkan variasi variabel dependen.

• Uji Serentak (Uji F)
Uji F digunakan untuk menguji
apakah model regresi dapat
digunakan untuk memprediksi

variabel dependen. Jika angka signifikansi lebih kecil dari 0,05 maka model regresi layak digunakan untuk memprediksi variabel dependen (Ghozali,2001 : 47).

\section{- Uji Parsial (Uji t)}

Uji $\mathrm{t}$ dilakukan untuk melihat seberapa jauh pengaruh variabel independent secara individu dalam menerangkan variasi variabel dependent (Ghozali,2001:48).

\section{HASIL DAN PEMBAHASAN}

\section{Deskripsi dan Sejarah Perusahaan}

PT. Bali Pawiwahan / Coco Group dirintis tahun 1998 oleh pengusaha lokal Bali yang memiliki cita-cita luhur dan sangat tinggi untuk membuat sebuah perusahaan lokal yang berskala besar. Perusahaan diawali dari sebuah toko kecil yang berlokasi di Bali Galeria Nusa Dua (Sekarang Bali Collection).

Pada tahun 2000 perusahaan mulai membuka beberapa cabang di BandaraNgurah Rai Internasional dan Domestik, seperti BPW1, Bina Pura, BPW3 dan toko lainnya. Tahun 2006 perusahaan mengembangkan usahanya lagi, kali ini mencoba pangsa pasar lokal dengan nama Coco Mart pada tanggal 25 Maret 2006. Di tahun yang sama tepatnya tanggal 20 November 2006 perusahaan juga membuka Coco Supermarket di area Bali Collection. Hingga kini perusahaan terus berkembang seiring dengan makin banyaknya para profesional yang bergabung di Coco Group.

Hasil Penelitian Dan Pembahasan 


\section{Hasil Uji Validitas}

Sebuah instrumen dikatakan valid apabila mampu mengukur apa yang diinginkan dan dapat mengungkap data dari variabel yang diteliti secara tepat. Ketentuan suatu instrumen dikatakan valid apabila memiliki koefisien korelasi Pearson Product Moment (r) > 0,3 (Sugiyono,
2012. Uji validitas digunakan untuk mengukur sah atau tidaknya suatu kuesioner. Suatu kuesioner dikatakan valid jika pernyataan pada kuesioner mampu untuk mengungkapkan sesuatu yang akan diukur oleh kuesioner tersebut. Adapun hasil uji validitas yang ditunjukkan melalui penelitian ini dapat dilihat melalui Tabel berikut :

Hasil Uji Validitas Variabel Kualitas Pelayanan

\begin{tabular}{|l|l|l|l|}
\hline No & Indikator & Koefisien Korelasi & Keterangan \\
\hline 1 & X1.1 & 0,917 & Valid \\
\hline 2 & X1.2 & 0,905 & Valid \\
\hline 3 & X1.3 & 0,947 & Valid \\
\hline 4 & X1.4 & 0,919 & Valid \\
\hline 5 & X1.5 & 0,877 & Valid \\
\hline 6 & X1.6 & 0,878 & Valid \\
\hline
\end{tabular}

Sumber : Data diolah, 2018

Berdasarkan Tabel diatas dapat

variabel penelitian adalah valid untuk diketahui bahwa seluruh indikator dalam variabel kualitas pelayanan memiliki koefisien korelasi yang lebih besar dari 0,30. Sehingga dapat dikatakan bahwa keseluruhan item digunakan sebagai instrumen dalam penelitian atau pertanyaanpertanyaan yang diajukan dapat digunakan untuk mengukur variabel yang diteliti.

Hasil Uji Validitas Variabel Kepuasan Pelanggan

\begin{tabular}{|l|l|l|l|}
\hline No & Indikator & Koefisien Korelasi & Keterangan \\
\hline 1 & X2.1 & 0,868 & Valid \\
\hline 2 & X2.2 & 0,899 & Valid \\
\hline 3 & X2.3 & 0,902 & Valid \\
\hline 4 & X2.4 & 0,911 & Valid \\
\hline 5 & X2.5 & 0,918 & Valid \\
\hline 6 & X2.6 & 0,959 & Valid \\
\hline
\end{tabular}

Sumber : Data diolah, 2018

Berdasarkan Tabel diatas dapat diketahui bahwa seluruh indikator dalam variabel kepuasan pelanggan memiliki koefisien korelasi yang lebih besar dari 0,30. Sehingga dapat dikatakan bahwa keseluruhan item variabel penelitian adalah valid untuk digunakan sebagai instrumen dalam penelitian atau pertanyaanpertanyaan yang diajukan dapat digunakan untuk mengukur variabel yang diteliti. 
Hasil Uji Validitas Variabel Keinginan Berbelanja

\begin{tabular}{|l|l|l|l|}
\hline No & Indikator & Koefisien Korelasi & Keterangan \\
\hline 1 & Y.1 & 0,926 & Valid \\
\hline 2 & Y.2 & 0,914 & Valid \\
\hline 3 & Y.3 & 0,917 & Valid \\
\hline
\end{tabular}

Sumber : Data diolah, 2018

Berdasarkan Tabel diatas dapat diketahui bahwa seluruh indikator dalam variabel keinginan berbelanja memiliki koefisien korelasi yang lebih besar dari 0,30. Sehingga dapat dikatakan bahwa keseluruhan item variabel penelitian adalah valid untuk digunakan sebagai instrumen dalam penelitian atau pertanyaanpertanyaan yang diajukan dapat digunakan untuk mengukur variabel yang diteliti.

\section{Uji Reliabilitas}

dimaksudkan untuk mengetahui

Hasil Uji Reliabilitas Kuesioner

\begin{tabular}{|l|l|l|l|l|}
\hline Hasil Uji Reliabilitas Kuesioner \\
\hline No & Variabel & Cronbach Alpha & No Item & Keterangan \\
\hline 1 & X1 (Kualitas Pelayanan) & 0,955 & 6 & Reliabel \\
\hline 2 & X2 (Kepuasan Pelanggan) & 0,957 & 6 & Reliabel \\
\hline 3 & Y (Keinginan Berbelanja) & 0,906 & 3 & Reliabel \\
\hline
\end{tabular}

Sumber : Data diolah, 2018 adanya konsistensi alat ukur dalam penggunaannya, atau dengan kata lain alat ukur tersebut mempunyai hasil yang konsisten apabila digunakan berkali-kali pada waktu yang berbeda. Suatu kuesioner diakatakan reliabel atau handal jika jawaban seseorang terhadap pernyataan adalah konsisten atau stabil dari waktu ke waktu. Untuk mengukur reliabilitas dengan uji statistik Cronbach Alpha lebih besar dari 0,6. Adapun hasil uji reliabilitas yang dilakukan terhadap instrumen penelitian ini dapat dijelaskan pada Tabel 4.8 berikut ini : 
Berdasarkan Tabel di atas, teknik pengujian reliabilitas menggunakan metode Cronbach Alpha. Nilai koefisien Cronbach Alpha berada di atas 0,06 atau > 0,06 sehingga semua instrumen tersebut adalah reliabel. Hal ini berarti bahwa item yang digunakan akan mampu memperoleh data yang konsisten dalam arti jika pertanyaan tersebut diajukan lagi maka akan diperoleh jawaban yang relative sama.

\section{Analisis Asumsi Klasik}

\section{Uji Normalitas}

Dapat dijelaskan bahwa garis diagonal dalam grafik ini menggambarkan keadaan dari data yang mengikuti distribusi normal. Titik-titik disekitar garis adalah keadaan data yang kita uji. Maka dapat disimpulkan bahwa data (titik) menyebar di sekitar garis diagonal dan mengikuti arah garis diagonal atau grafik histogramnya menunjukkan pola distribusi normal, maka model regresi memenuhi asumsi normalitas.

\section{Uji Multikolinieritas}

Dapat dijelaskan bahwa Nilai Tolerance variabel kualitas pelayanan (X1) dan kepuasan pelanggan (X2) yakni 0,729 lebih besar dari 0,10. Sementara itu, Nilai VIF (Variance Inflation Factor) variabel kualitas pelayanan (X1) dan kepuasan pelanggan (X2) yakni 1,373 lebih kecil dari 10,00. Sehingga dapat disimpulkan tidak terjadi Multikolinieritas.

\section{Uji Heteroskedastisitas}

Bahwa titik-titik menyebar dan tidak membentuk pola tertentu yang jelas.
Sehingga dapat disimpulkan bahwa tidak terjadi masalah Heteroskedastisitas.

\section{Analisis Regresi Linear Berganda}

Dari hasil regresi pada Tabel 4.10 maka dapat disusun persamaan regresi sebagai berikut :

$$
\begin{aligned}
& Y=a+b_{1} X_{1}+b_{2} X_{2} \\
& Y=-0,465+0,236 X_{1}+0,289 X_{2}
\end{aligned}
$$

Berdasarkan hasil persamaan ini, dapat dijelaskan pola kualitas pelayanan $\left(\mathrm{X}_{1}\right)$, kepuasan pelanggan $\left(\mathrm{X}_{2}\right)$ terhadap keinginan berbelanja (Y) yaitu sebagai berikut :

- $\quad \mathrm{a}=-0,465$ berarti apabila kualitas pelayanan (X1) dan kepuasan pelanggan (X2) tidak mengalami perubahan (sama dengan nol) atau tetap maka besarnya keinginan berbelanja (Y) adalah -0,465.

- $\quad b_{1}=0,236$ berarti apabila kualitas pelayanan $\left(\mathrm{X}_{1}\right)$ dinaikkan satu satuan (1) dan variabel kepuasan pelanggan $\left(\mathrm{X}_{2}\right)$ tidak berubah maka keinginan berbelanja (Y) meningkat sebesar 0,236 satuan. Artinya setiap peningkatan kualitas pelayanan dapat meningkatkan keinginan berbelanja.

- $\quad b_{2}=0,289$ berarti apabila variabel kepuasan pelanggan $\left(\mathrm{X}_{2}\right)$ dinaikkan satu satuan (1) dan variabel kualitas pelayanan $\left(\mathrm{X}_{1}\right)$ tidak berubah maka dapat meningkatkan keinginan berbelanja sebesar 0,289. Artinya setiap peningkatan kepuasan pelanggan dapat meningkatkan keinginan berbelanja.

\section{Analisis Korelasi Berganda}

Hasil yang diperoleh koefisien korelasi sebesar $\mathrm{R}=0,889$. Berdasarkan kriteria kuat lemahnya hubungan menurut 
Sugiyono (2010), maka koefision korelasi 0,889 diatas terletak antara 0,80-1,00 yang berarti terdapat korelasi yang sangat kuat, ini berarti bahwa pengaruh antara kualitas pelayanan $\left(\mathrm{X}_{1}\right)$ dan kepuasan pelanggan $\left(\mathrm{X}_{2}\right)$ dengan keinginan berbelanja (Y) adalah sangat tinggi.

\section{Koefisien Determinasi $\left(\mathbf{R}^{2}\right)$}

Hasil uji yang diperoleh besarnya determinasi $\left(R^{2}=0,790\right)$, ini berarti pengaruh kualitas pelayanan dan kepuasan pelanggan terhadap keinginan berbelanja sebesar $79,0 \%$ sedangkan sisanya sebesar $21,0 \%$ dipengaruhi oleh faktor lain diluar penelitian ini.

\section{Uji Serentak (Uji f-test)}

Hasil perhitungan Uji $\mathrm{F}$ pada Tabel 4.13 diatas, dapat dilihat dari Tabel diperoleh nilai $f_{\text {hitung }}$ sebesar 107,371 dengan nilai probabilitas $(\operatorname{Sig})=0,000$. Nilai $F$ hitung $(107,371)>$ F tabel $(3,15)$ maka variabel independent (bebas) secara simultan berpengaruh terhadap variabel dependent (terikat) dan nilai sig lebih kecil dari nilai probabilitas 0,05 atau nilai $0,000<0,05$ maka variabel independent (bebas) secara bersama-sama berpengaruh signifikan terhadap variabel dependent (terikat).

\section{Uji Parsial (Uji t)}

Hasil perhitungan Uji t pada Tabel 4.14 diatas dapat dijelaskan bahwa: Kualitas pelayanan $\left(\mathrm{X}_{1}\right)$ terhadap keinginan berbelanja (Y) terlihat pada kolom Coefficients model 1 terdapat nilai sig 0,000. Nilai sig lebih kecil dari nilai probabilitas 0,05 atau nilai $0,000<0,05$ maka, $\mathrm{Ha}$ diterima dan Ho ditolak. Variabel $\mathrm{X}_{1}$ mempunyai thitung yakni 6,440 dengan $\mathrm{t}_{\text {tabel }}=$
1,671. Jadi $t_{\text {hitung }}>t_{\text {tabel }}$ atau $6,440>1,671 \mathrm{ini}$ berarti bahwa variabel $X_{1}$ memiliki kontribusi terhadap variabel $\mathrm{Y}$.

\section{KESIMPULAN DAN SARAN}

\section{Kesimpulan}

Berdasarkan analisis yang telah dilakukan pada penelitian pengaruh kualitas pelayanan dan kepuasan pelanggan terhadap keinginan berbelanja pada Coco Mart Tabanan, maka dapat disimpulkan hasil penelitian sebagai berikut :

1. Variabel kualitas pelayanan dan kepuasan pelanggan berpengaruh signifikan terhadap keinginan berbelanja.

2. Dari analisis regresi linear berganda diperoleh persamaan $\mathrm{Y}=-0,465+0,236 \mathrm{X}_{1}+$ $0,289 \mathrm{X}_{2}$. Dari persamaan garis regresi linear ini menunjukkan bahwa terdapat pengaruh positif kualitas pelayanan dan pengaruh positif kepuasan pelanggan terhadap keinginan berbelanja.

3. Hasil koefisien korelasi berganda adalah 0,889 berarti secara simultan kualitas pelayanan dan kepuasan pelanggan mempunyai hubungan sangat tinggi terhadap keinginan berbelanja.

4. Hasil analisi determinasi berganda diperoleh koefisien determinasi adalah $79,0 \%$ berarti besarnya variasi pengaruh antara kualitas pelayanan dan kepuasan pelanggan terhadap keinginan berbelanja adalah $79,0 \%$ sedangkan sisanya $21,0 \%$ ditentukan oleh variabel lain diluar kualitas pelayanan dan kepuasan pelanggan yang tidak dijelaskan dalam penelitian.

5. Analisis uji $\mathrm{F}$ diperoleh $\mathrm{F}$ hitung $=107,371$ dibandingkan dengan nilai $F_{\text {tabel }}=3,15$ yang 
berarti bahwa pada taraf $\alpha=5 \%$ secara simultan kualitas pelayanan $\left(\mathrm{X}_{1}\right)$ dan kepuasan pelanggan $\left(\mathrm{X}_{2}\right)$ memiliki pengaruh yang signifikan (nyata) terhadap keinginan berbelanja (Y).

6. Dalam uji signifikansi parsial (uji t), variabel kualitas pelayanan $\left(\mathrm{X}_{1}\right)$ signifikan mempengaruhi keinginan berbelanja (Y) dengan nilai $t_{\text {hitung }}=6,440$ dibandingkan dengan nilai $t_{\text {tabel }}=1,671$ maka ternyata nilai $t_{\text {hitung }}$ lebih besar dari nilai $t_{\text {tabel }}$ atau $t_{\text {hitung }}$ $6,440>t_{\text {tabel }} 1,671$ ini berarti bahwa dalam keadaan kepuasan pelanggan $\left(\mathrm{X}_{2}\right)$ konstan, secara statistika pada taraf kepercayaan $(\alpha)=$ $5 \%$ maka, kualitas pelayanan $\left(\mathrm{X}_{1}\right)$ berpengaruh positif signifikan (nyata) terhadap keinginan berbelanja (Y). Dengan demikian hipotesis teruji kebenarannya. Sedangkan variabel kepuasan pelanggan $\left(\mathrm{X}_{2}\right)$ signifikan mempengaruhi keinginan berbelanja dengan nilai $t_{\text {hitung }}=7,880$ dibandingkan dengan nilai $t_{\text {tabel }}=1,671$ maka, ternyata nilai thitung lebih besar dari nilai $t_{\text {tabel }}$ atau $t_{\text {hitung }} 7,880>t_{\text {tabel }} 1,671$ ini berarti bahwa dalam keadaan kualitas pelayanan $\left(\mathrm{X}_{1}\right)$ konstan, secara statistika pada taraf kepercayaan $(\alpha)=5 \%$, kepuasan pelanggan $\left(\mathrm{X}_{2}\right)$ berpengaruh positif signifikan (nyata) terhadap keinginan berbelanja (Y). Dengan demikian hipotesis teruji kebenarannya (Ho ditolak).

\section{Saran}

Berdasarkan hasil analisis yang diperoleh melalui penelitian ini maka, saran - saran yang dapat disampaikan kepada perusahaan terkait penelitian mengenai pengaruh kualitas pelayanan dan kepuasan pelanggan terhadap keinginan berbelanja pada Coco Mart Tabanan adalah sebagai berikut :
1. Melakukan pembinaan sumber daya manusia melalui pertemuan intern berkala dan mengikutsertakan dalam pelatihan teknis pelayanan kepada pelanggan dan kursus pengembangan diri guna peningkatan skil dan sikap perilaku kerja sesuai konsep pelayanan prima.

2. Perlu peningkatan kemudahan yang harus diberikan kepada pelanggan dalam mendapatkan produk dengan tidak perlu datang ke toko, cukup melalui telepon dan dilakukan pengantaran ke alamat yang diminta pelanggan dengan tidak menaikan harga per kilogramnya melebihi pesaing sehingga pelanggan menjadi lebih puas.

3. Disarankan kepada peneliti mendatang untuk memperluas obyek penelitian, tidak hanya di Coco Mart, tetapi juga di toko lainnya (Alfamart, Indomaret dan pada toko yang sedang maupun sudah berkembang), variabel penelitian diperbanyak dan pengambilan data tidak ditekankan pada kuesioner, tetapi juga perlu dilakukan wawancara mendalam sehingga interpretasi secara kualitatif menjadi dalam.

\section{DAFTAR PUSTAKA}

Abdullah, Thamrin. 2003. Manajemen Pemasaran. Jakarta: PT Rajawali Pers.

Agung Afrinto. 2006. Pengaruh Kualitas Pelayanan Terhadap Kepuasan Pelanggan Dalam

Intensi Pembelian. Skripsi. Universitas Negeri Semarang.

Engel, F. James; Roger D. Blackwell; Paul W. Miniard. 2010. Perilaku Konsumen. Jakarta: Binarupa Aksara. 
Aribawanti, Diaz. 2004. Analisis Pengaruh Kualitas Kinerja Layanan Dengan Reputasi Merek

Dan Kepuasan Nasabah (Studi Kasus: Bank BNI Kantor Cabang Karangayu Semarang).

Tesis. PPS. STIE Stikubank Semarang.

Arief dan Wyckof. 2007. Pemasaran Jasa Dan Kualitas Pelayanan. Malang: Banyumedia Publishing.

Assel, Henry. 2002. Consumer Behavior and Marketing Action. Boston: Keat Publishing Company.

Berry dan A Pasuraman. 2003. Jurnal Pengaruh Kualitas Pelayanan TerhadapKepercayaan. Vol 21.2430(Januari2003).

Donni Juni Priansa, S.Pd., S.E., M.M., QWP. 2016. Perilaku Konsumen Dalam Persaingan

Bisnis Kontemporer. Bandung: ALFABETA

Dutka, Alan. 2008. AMA Hand Book for Customer Satis Faction. NTC Business Book. Lincoln Wood, Illinois.

Freddy Rangkuti. 2009. Strategi Promosi yang Kreatif. Edisi Pertama. Cetakan Pertama.

Penerbit : Gramedia Pustaka Utama, Jakarta.

Ghozali. 2001. Aplikasi Analisis Multivariate Dengan Program SPSS. Badan Penerbit:

Universitas Diponegoro, Semarang.
Handi Irawan. 2009. 10 Prinsip Kepuasan Pelanggan. Cetakan Ketujuh. Jakarta : Elex Media Komputindo.

Hardiansyah. 2011. Kualitas Pelayanan Publik. Yogyakarta : Gava Media.

Howard, J. A and Sheth, J. N, 1969. The Theory Of Buyer Behavior, (Edisi Cetak Ulang) New York : John Wiley and Sons.

Juran, J. M. 1992. Total Quality Management: A Practical Guide. Connecticut: Juran Institute, Inc.

Kotler, Philip. 2000. Manajemen Pemasaran : Anlisis Perencanaan, Implementasi dan

Pengendalian. Edisi 6 Jilid 2. Jakarta : Erlangga.

Kotler, Philip and Keller, Kevin Lane. 2012. Marketing Management. New Jersey: Prentice Hall.

Kotler, Philip dan Gary Amstrong. 2012. Principles OfMerketing. Global Edition. PearsonEducation.

Leudon, David L and Bella Bitta, Albert L. 1993. Lontemporary Marketing Plus (Eight Edition International Edition). The Dryden Hall.

Philip, Kotler. 1997. Manajemen Pemasaran. Edisi Bahasa Indonesia jilid satu. Jakarta :Prentice Hall.

Schiffman L.G.L.L Kanuk and J Wisen Blit. 2010. Cosumer Behavior. Tenth Edition Prentice Hall New Jersey. 
Sugiyono. 2010. Metode Penelitian

Pendidikan Pendekatan Kuantitatif, Kualitatif dan R\&D.Bandung: ALFABETA.

Sugiyono. 2013. Statistik Untuk Penelitian. Bandung : CV Alfabeta.

Solomon, Michael R. 2011. Consumer Berhavior: Buying, Having, and Being. New Jersey, USA: Pearson Prentice Hall.

Swastha, Basu dan Irawan. 2005. Manajemen Pemasaran Modern. Yogyakarta: Liberty.

Tjiptono, Fandy. 2001. Manajemen Jasa, Edisi Kedua, Yogyakarta : Andi Offset.

Tjiptono, Fandy dan Candra, Gregorius. 2011. Service, Quality, \& Satisfaction. Edisi Ketiga. Yogyakarta: Penerbit Andi. 